Preliminary communication

UDC: 330.565

doi:10.5937/ekonhor1702141W

\title{
INCOME INEQUALITY: DOES IT MATTER?
}

\author{
Alfred Wong* and Christine Ribeiro \\ Arbokem Inc., Vancouver, Canada
}

\begin{abstract}
Income inequality has gained considerable prominence worldwide in recent years. The growing discontent among the lower-income segment of industrialized societies is limited largely to resentment because of economic wealth being perceived to be steadily concentrating among fewer people. Quantified economic inequality does not necessarily mean the extreme deprivation of people, especially in Europe and North America. There will be no revolutionary-scale social unrest among the middle class if their expectation of satisfactory wellbeing is continually met. The connection between income inequality and poverty is uncertain because of the variable definition of poverty. The classical characterization of poverty is largely deficient as the actual economic hardships encountered by the lowest-income segment of society are never fully described in the socio-geographic context. What is deprivation in Europe and North America may be considered to be "luxurious" in economically poorer countries.
\end{abstract}

Keywords: exploitation, inequality, minimum wage, poverty, social justice

JEL Classification: D31, D33, D63, J31

\section{INTRODUCTION}

During the past decade, income inequality has become a popular topic of discourse among economists and social scientists in many developed countries. Numerous papers, monographs, reports and books (Stiglitz, 2012; Cingano, 2014; OECD, 2014; Piketty, 2014; Dabla-Norris, Kochhar, Suphaphiphat, Ricka \& Tsounta, 2015; Milanovic, 2016) have been published on this subject. Most of the discourse has been made notably within the framework of neoliberal economics. The orthodox contention is that "income inequality is bad for business". Some

* Correspondence to: A. Wong, Arbokem Inc., Post Office Box 34173 Vancouver V6J 4N1, Canada;

e-mail: arbokem@arbokem.com economists naïvely suggest that greater economic transparency would lead to the democratic control of capital for the common good (Piketty, 2014, 569570). This reasoning is completely contrary to the fundamental tenant of the existence of the "modern corporation", whose sole purpose is the maximization of a profit for its shareholders by whatever means available (Friedman, 1962; 1970). Indeed, executives are routinely hired (and handsomely paid) to achieve this goal. Externalities could not and would not be the factors of importance. In essence, transparency and democracy have no relevance in this context.

In reality, the capitalist economy declines when there is no gross income inequality. One method for achieving maximum profit maximization is to "drive down" the cost of inputs. For example, if a 
food market business operates in order to maximize its profit, it always strives to reduce its own labor cost and squeeze the suppliers to cut price. This paradigm inevitably creates economic inequality.

There is a paucity of the critical analysis of the underlying facets of income inequality and its possible relationship to poverty in a capitalist society. Neither "absolute poverty" nor "relative poverty" is the satisfactory measure of the hardships endured by the lowest-income segment of society in supporting this askew economic structure. In defining poverty, the two items of vital importance are food and a shelter in contemporary societies. Ancillary education and health care are routinely provided as essential services by governments in developed countries.

This paper is aimed at exploring some of the inconsistencies and contradictions in the present discourse on economic inequality. In particular, the analysis would be focused on the perplexing issues of the characterization of economic inequality, the relative meaning of real or perceived economic inequality and the inevitability of economic inequality. The European Union is deployed to be the principal analytical setting.

\section{METHODS}

The data published by international agencies, such as the United Nations Development Programme, the World Bank and the Organization for Economic Cooperation and Development were used for the present analysis. It is important to note that the international data are based largely on the data supplied by the member states of the respective organizations. Therefore, these data are prone to be purposefully omitted and distorted by data suppliers for their own national purposes. Such manipulations by national authorities are known in many instances elsewhere (MacCoun, 2001; Webster, 2012). These data were thus cautiously used.

In this paper, the terms "income" and "wealth" are used interchangeably because in a cash-based economy, there is the considerable convertibility of wealth (in the form of holdings of goods, for example) into cash income, which becomes a potentially taxable earning. Thus, the inequality of income and the inequality of wealth have essentially the same meaning. In contrast, wealth has innately a very different meaning in cashless Stone-age economics, as there is no monetization of goods or services (Sahlins, 1972, 2-10).

In the present study, the "middle class" is defined as a group of people with middle (salaried) income, regardless of the social class or the employment type. In contemporary economic literature, the middle class is often comprised of merchants, educated professionals and managerial workers. In the Marxist social schema, the middle class is defined as the people below the ruling elites and above the proletariat.

\section{RESULTS AND DISCUSSION}

\section{How Should Economic Inequality Be Characterized?}

One of the most widely used indices of income inequality is the Gini coefficient ${ }^{1}$. Briefly said, the Gini coefficient measures the extent to which the distribution of income or the consumption expenditure among individuals or households within an economy deviates from a perfectly equal distribution. The Lorenz curve plots the cumulative percentages of the total income received against the cumulative number of the recipients, starting with the poorest individual or household. The Gini coefficient measures the area between the Lorenz curve and the hypothetical line of absolute equality, expressed as a fraction of the maximum area under the line. Thus, the Gini coefficient of " 0 " represents perfect equality, whereas the coefficient of "1" implies perfect inequality (World Bank, 2016a). Figure 1 illustrates the basic concept of the Gini coefficient. The example of the Lorenz curve shown represents a situation in which $10 \%$ of the population accounts for $90 \%$ of the wealth and the remaining $90 \%$ of the population 


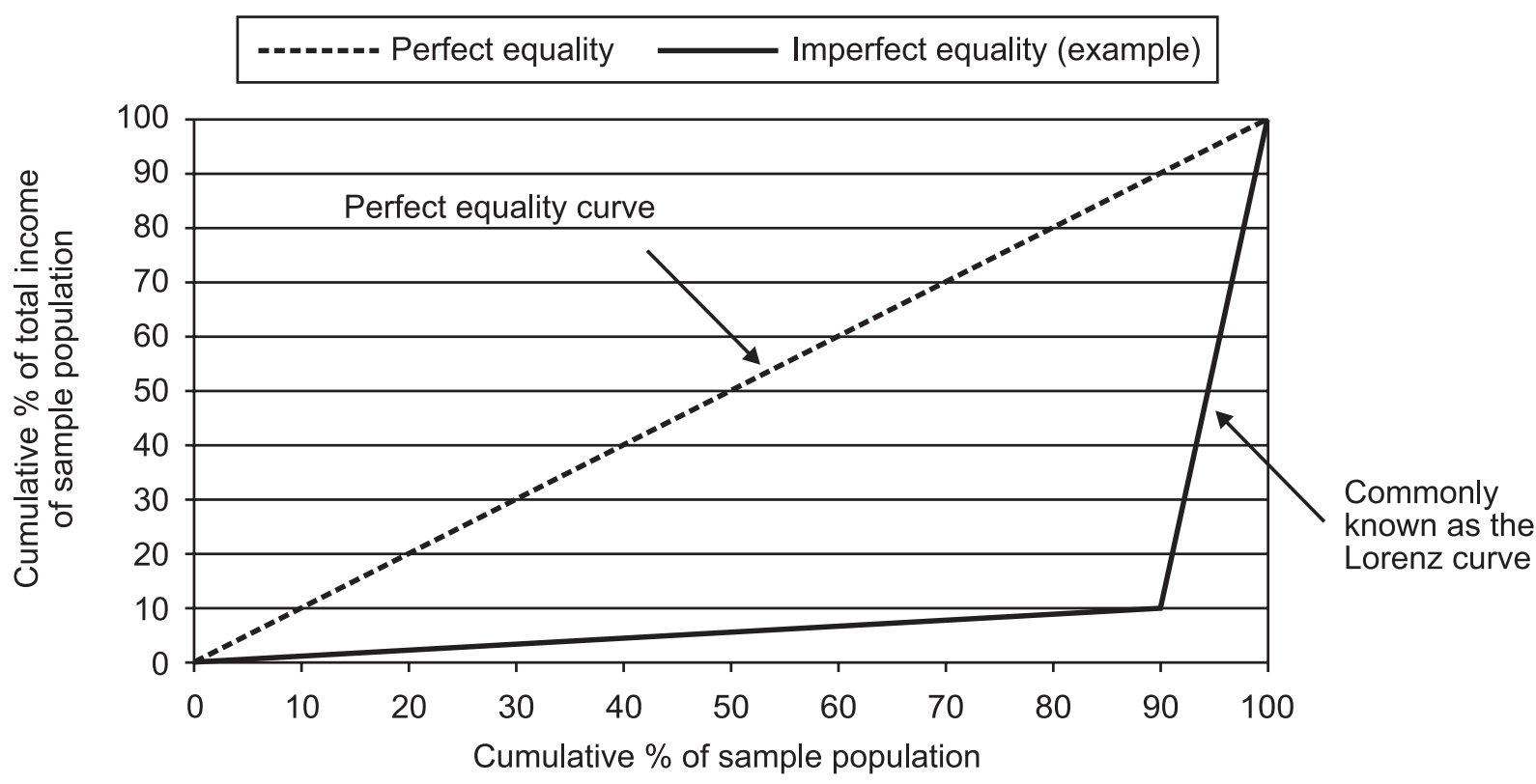

Figure 1 The illustrative Gini coefficient depicting income inequality

Source: Authors

accounts for $10 \%$ of the wealth. The calculated Gini coefficient is 0.900 in this instance.

In principle, the concepts of the Lorenz curve and the Gini coefficient are sound. Their practical application, however, is fraught with at least two systemic problems: the shape of the Lorenz curve is not uniform so as to afford the same differential area between the perfect equality curve and the Lorenz curve, and the accuracy of the calculated Gini coefficient is totally dependent on the completeness of reporting all the income (or wealth) of all the counted citizens.

\section{Deficiencies}

Typically, only the reported income subject to taxation is used for these social-economic analyses. In practice, the wealthy segment of a population has various legal (as well as not specifically illegal) means to minimize income for the taxation purposes (Alstadsaeter \& Martin, 2013). A wealthy individual or a wealthy family could incorporate in Ireland,
Luxemburg and the Grand Cayman Island serially to reduce the largest portion of its/their "corporate" income for the purpose of reporting it for the taxation purposes by any jurisdiction. Thus, the income share of the wealthy segment of a population might indeed be substantially higher. According to Alstadsaeter, Johannesen \& Zucman (2017), 40\% of the richest 0.1 of the Norwegian households hid their assets offshore. In contrast, the low income segment of the population has of course no means to pay creative financial planners and tax lawyers to devise the ingenious legal methods of tax avoidance. Without the full accounting of all hidden incomes, the Gini coefficient would not and could not reflect the true state of the economic distribution of a nation state. Indeed, the accuracy of the Lorenz curve construction is totally dependent on the completeness of the (taxable) income data of a polity. Any deficiency in the fidelity of the primary data could substantially distort the subsequent calculation of the Gini coefficient.

In a globalized just society, all tax havens would be shut down. But they persist. For example, the 
notorious British colonies in the Caribbean, viz., British Virgin Islands, Grand Cayman and Turk and Caicos are widely recognized as efficient tax havens. Successive British governments have routinely offered the disingenuous excuse that they have had no legal means to eliminate these tax havens. In fact, these overseas territories are ruled directly by the British colonial authority residing in London. The British colonial authority has the absolute power to shut down these tax havens at will, if it chooses to do so. The underlying reason for the lack of a meaningful remedial action might be that the shutting down of these tax havens would affect adversely many wealthy supporters, i.e. individuals as well as corporations, of the British political establishment. Nevertheless, despite the fiscal necessity of tax collection, the elimination of tax evasion may only impact the statistics of economic inequality. And there may be no other matters of consequence.

\section{Inaccuracies}

Is the true state of income inequality accurately reflected by the generally accepted metrics in a given capitalist country? In particular, the underlying issue is whether income equality, as depicted by the Gini coefficient, is numerically meaningful at all? Table 1 shows that the same value of the Gini coefficient does not reflect the wellbeing of the citizens of the two groups of the selected countries. On the basis of the national averages, life, as depicted by the personal acquisition of material goods, is generally recognized to be much more meagre in Ethiopia or Guinea than in Canada. And yet, the Gini coefficient is notably comparable.

Note that in Group I, the essential difference in the "quality of life" is coincidentally reflected only in the Human Development Index (HDI) ${ }^{2}$. The HDI of Canada is reported to be more than twice as high as that of Ethiopia or Guinea. In Group II, good life, as characterized by the acquisition of material goods in Belarus or Ukraine, is generally recognized to be substantially worse than that in Denmark. Interestingly, Ukraine has a lower Gini coefficient, i.e. there is greater equality in wealth distribution, than
Denmark, the epitome of a "good-life" equalitarian member state of the European Union. In reality, unfettered endemic corruption in both Ukrainian private and public sectors allows economic income to remain grossly unreported and under-reported. Thus, in this instance, the favorable Gini coefficient calculated for Ukraine is definitively inaccurate.

Table 1 The selected comparison of the three classes of the Gini Index

\begin{tabular}{c|lcc}
\hline Group & Country & $\begin{array}{c}\text { Gini } \\
\text { Coefficient* }\end{array}$ & $\begin{array}{c}\text { Human } \\
\text { Development } \\
\text { Index** }\end{array}$ \\
\hline I & Canada & 0.337 & 0.913 \\
& Ethiopia & 0.336 & 0.442 \\
& Guinea & 0.337 & 0.411 \\
\hline$I I$ & Denmark & 0.269 & 0.923 \\
& Belarus & 0.265 & 0.793 \\
& Ukraine & 0.248 & 0.747 \\
\hline
\end{tabular}

Notes:

* Gini Coefficient $=1.00$ implies the perfect inequality of income; Gini Coefficient $=0$ implies the perfect equality of income.

** Human Development Report 2015; Data Year 2014

Source: Authors, based on: World Bank, 2016a; UNDP, 2015

The deployment of the Gini coefficient in order to compare economic income (or wealth) is virtually meaningless. Its persistent use by national and international institutions (Milanovic, 2013; 2016; World Bank, 2016a) is indeed puzzling with respect to this obvious misrepresentation.

\section{Different Implications}

From another perspective, Figure 2 shows the two constructed example cases of the paradoxical deficiency of the Gini coefficient. Note that the area between the Gini curve and the Lorenz curve in Case " $\mathrm{A}$ " is identical to the area between the Gini curve and the Lorenz Curve in Case " $\mathrm{B}$ ". The societal implications, however, are very different in each case. 
In Case $\mathrm{A}, 80 \%$ of the population is in fact the slaves without any monetary income. The Haiti of the $18^{\text {th }}$ century is a classical illustration of this type of wealth distribution (Popkin, 2012). Expendable slaves were regularly imported from Africa to work in Haitian sugar cane fields; they were only minimally provided with food and shelter. French colonialists, such as administrators and armed guards, were paid a certain sum of money to maintain order in the slave-operated plantations. The remaining large quantity of money generated by the slaves' labor was appropriated by the plantation owners residing in France.

In Case $B$, the representative example would be Saudi Arabia, in which certain amounts of money are distributed to officially-recognized citizens, including civil servants and soldiers. The self-styled hereditary royalties personally hold the vast amount of the remaining national wealth.

What is dangerous is that the particular income distribution pattern of Case $\mathrm{A}$ is highly prone to substantial social unrest. Indeed, after several decades of labor strife, penury slaves overthrew the French colonialists with the aim of founding the new nation of Haiti in 1812. In the contemporary example of Equatorial Guinea, the family and friends of

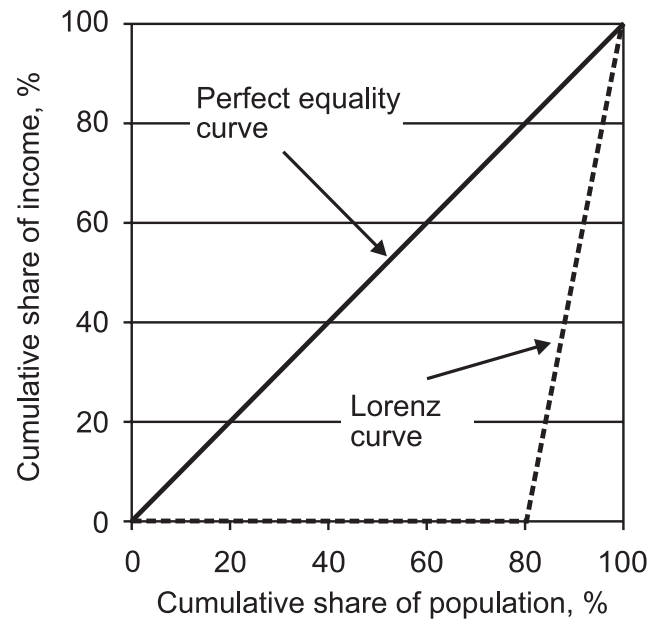

Case A: Gini coefficient $=0.800$
President for Life Obiang own everything (Sundiata, 1990; Petrovic, 2012). The remaining population has virtually nothing; their basic needs have equilibrated over time to become very sparse. Because of the peculiar disperse island geography of Equatorial Guinea the expected mass social unrest has not emerged. In Case B, social unrest is less likely if and only if the lifestyles (and the material expectations) of the non-royalty citizens are always satisfactorily met by distributed funds. An example of such a corrective action taken to avert fomenting social unrest is the recent decision of the ruling regime of Saudi Arabia to restore benefits to their state employees (Anon, 2017). It may be noted that the wellbeing of imported migrant workers is officially deemed to have no consequences as they are expendable, i.e. summary deportation and an over-subscribed replacement. In the particular case of Saudi Arabia (as well as in many Persian Gulf Emirates), non-citizens, i.e. foreign laborers from Asia and Africa, who constitute a large fraction of the resident population ${ }^{3}$, have virtually no wealth of any kind. These laborers are essentially slaves (ITUC, 2014). These semi-permanent residents are routinely excluded from the national census. To a large extent, the Case B scenario might be likened to the present situation in the EUSAC (Europe, United

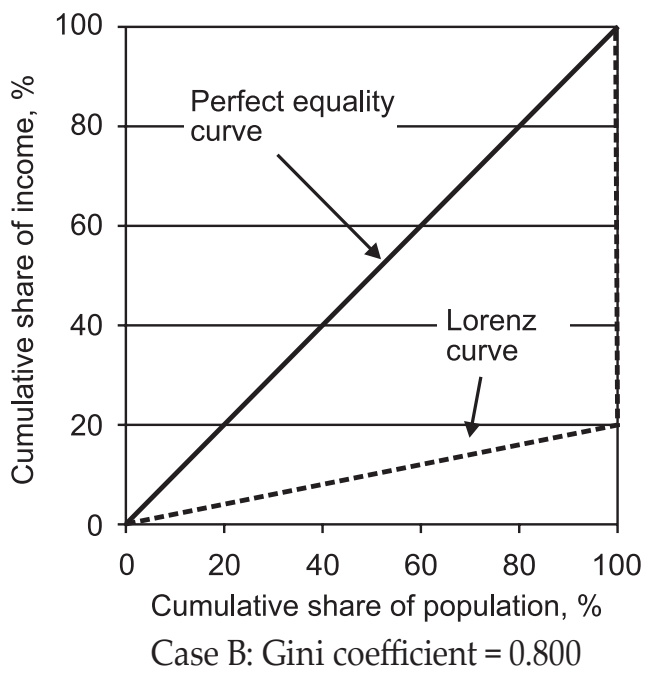

Figure 2 The identical Gini coefficient depicting two different income distributions 
States of America, Australia and Canada; commonly referenced incorrectly as "the West") societies, in which the middle class group receive sufficient economic income (and benefits) for immediate satiety for continued societal stability. There is little or no revolutionary-scale social unrest.

\section{What is the meaning of income inequality?}

The defining of income inequality is elusive as this parameter is temporal and site-specific. Moreover, the choice of the definition of economic inequality is generally recognized to be dependent on the personal or institutional ideology of the socio-economic policy analysts.

\section{The Context}

It is evident that in different countries income inequality has a variable meaning and a variable impact. For example, the social consequences of income inequality in the Democratic People's Republic of Korea (DPRK) are very dissimilar to those in the Republic of Korea (RoK). The economic system of each adjoining country is very different. In the DPRK, most people enjoy the basic necessities of life equally, albeit in a much meagre amount than those enjoyed by the people living in the RoK. Unlike Seoul, there are no homeless people living in the streets in Pyongyang. The lower consumption of meat in the daily diet of the citizens of the DPRK does not necessarily mean deprivation. There is thus no logical reason why the wellbeing of the people (of different countries) should simply be compared only through the prism of a single classical capitalism paradigm.

\section{The Expectations}

Although there may be the elements of perceived unfairness and decreased governance in a highlypublicized discourse on economic inequality (Slemrod, 2007; Zucman, 2014), tax evasion is merely an issue of calculating economic inequality by the statistics authorities of many nation states. Reduced fiscal income for the government is a driving force for the eradication of tax evasion (Alstadsaeter et al, 2017). However, there is no guarantee that the recovered revenue would have been spent on social goods for the underclass. Indeed, the money retrieved from tax evaders might well be spent on the purchase of more frivolous military hardware for a defense against the real or fictitious enemies of the State.

For social and cultural reasons, Ireland should be expected to have a very different definition of poverty, i.e. subsistence, from Latvia. Table 2 illustrates the relative income of the selected groups of citizens in Latvia and Ireland. According to the published Gini coefficients, Latvia would seemingly be less unequal than Ireland. A direct comparison of economic inequality by applying this method is not meaningful for the reasons previously discussed. As in the other EU member states, the actual wealth at the top segment of the Irish or the Latvian population is generally recognized to be extremely difficult to quantify as this group has the unique ability and resource to hide wealth using various instruments, including off-shore personal and corporate bank accounts.

It is generally recognized that the middle income group in Latvia do not enjoy the same "good standard of living" as that in Ireland (Wong, 2016). At a gross annual income of $\sim € 47,000$, a person could enjoy a good "standard of living" in Ireland, with respect to an apparent inequality of more than $90 \%$ of the wealth owned by less than $5 \%$ of the population. In both Ireland and Latvia, a large income disparity might have no impact on the wellbeing of this segment of the population, even if the last $5 \%$ of the population owned more than $99.9 \%$ of the national wealth. Although the resentment of the collective public might increase as "rich people are getting richer", the critical element is whether the expectation of the satisfactory living standard of the middle income group could be met and maintained continually. In practical terms, the actual difference of the economic disparity, i.e. "the top segment owning everything", is irrelevant. 
Table 2 The income pattern in Ireland and Latvia

\begin{tabular}{|c|c|c|c|}
\hline & Ireland & Latvia & Remarks \\
\hline Gini coefficient, 2003-2015 average & 0.321 & 0.360 & UNDP (2015) \\
\hline HDI, 2014 & 0.916 & 0.819 & UNDP (2015) \\
\hline Paid work, hours per month & 158 & 183 & 2014 data (EC, 2017a) \\
\hline \multicolumn{4}{|l|}{ Low-wage threshold } \\
\hline$€$ per hour & 13.40 & 2.20 & 2014 data (EC, 2017a) \\
\hline$€$ per year & 25,406 & 4,831 & Calculated \\
\hline$\%$ of population & 4.1 & 7.9 & $\begin{array}{l}2014 \text { data (EC, } 2017 \mathrm{~b}) ; \% \text { of low wage earners = } \\
\text { persons earning less than } 10 \% \text { of the national } \\
\text { minimum wage }(\mathrm{EC}, 2017 \mathrm{~b})\end{array}$ \\
\hline \multicolumn{4}{|l|}{ Median gross earnings } \\
\hline$€$ per hour & 20.20 & 3.40 & 2014 data (EC, 2017a) \\
\hline$€$ per year & 38,299 & 7,466 & Calculated \\
\hline
\end{tabular}

Source: Authors, based on: UNDP, 2015; EC, 2017a; 2017b

\section{Poverty}

There is no rational reason for us to believe that chronic poverty is caused singularly by economic inequality. Nevertheless, in Ireland, as well as elsewhere in the European Union, various attempts have been made to equate economic inequality with chronic poverty (Dennis \& Guio, 2004; Barone \& Guio, 2005; Guio, 2005; Antuofermo \& Di Meglio, 2012; Doran \& Jordan, 2013). Since 2013, the Irish Economic and Social Research Institute (EAPNI, 2017) has identified the defining criteria to be: a) people with less than $60 \%$ of national median income and b) people being deprived of at least two of the 11 indicators given in Table 3. It is obvious that many of the indicators given in Table 3 are only relevant to the social conditions of the "wealthy" states in the EU. For example, people living in Latvia might not be defined to be poor in the absence of meeting most of the 11 listed goods and services considered as essential for the basic living standard for the Irish. In Latvia, as well in many "less prosperous" EU member states, only Item 7 of Table 3 (in addition to minimal food and shelter) would be deemed to be absolutely necessary for human survival.
Table 3 Deprivation indicators - Ireland 2015

1 Two pairs of strong shoes

2 A warm waterproof overcoat

3 Buy new, not second-hand clothes

4 Eat meals consisting of meat, chicken, fish (or a vegetarian equivalent) every second day

5 Have a roast joint or its equivalent once a week

6 Had to go without heating during the last year through a lack of money

7 Keep the home adequately warm

8 Buy presents for the family or friends at least once a year

9 Replace any worn-out furniture

10 Have the family or friends for a drink or meal once a month Have had a morning, afternoon or evening out in the last fortnight, for entertainment

Source: Authors, based on: EAPNI, 2017 
The veritable quantification of poverty requires its separation from the characterization of economic inequality. The assessment of comparative poverty is not practicable, even when the "basket of goods" and the purchasing power parity concepts are introduced. Note that both countries are in the Eurozone. The important matter is the fact that the citizens of each country have a different dietary and cultural pattern. By ignoring the different cultural context, any such comparison is systemically incorrect. In the case of Ireland and Latvia, A. Wong (2016) has proposed a simple measure of relative poverty by using a standardized fare for air travel between Dublin and Riga on the same target date. The resulting calculation has suggested that the average Irish is about three times wealthier (financially) than the average Latvian. However, the unaffordability of the Latvians to travel abroad does not necessarily mean poverty and certainly does not arise from economic inequality.

\section{Is It Obscene to Be Wealthy?}

According to the Oxford Dictionary (9 $9^{\text {th }}$ Edition), "obscene" is defined as being "offensively or repulsively indecent". Decency itself is defined as being the "generally accepted standards of behaviour or propriety". These descriptors, however, are highly subjective and temporal. In a contemporary society functioning under the neoliberal economic model, making more money than everyone else is considered to be a virtue worthy of emulation. It logically follows that there should be absolutely no indecency in being highly wealthy by using whatever means available. There is no morality in fostering commonweal. Indeed, this concept of "spreading economic wealth" is often a deception deployed glibly by cunning politicians during election time.

\section{Is Economic Inequality Inherently Bad?}

\section{Differential Consequences}

There is no inherent reason why income inequality might be bad. It is a matter of relativity. For example, Britain was officially characterized to be "less equal" than Bangladesh in 2010, i.e. the Gini coefficients were 0.380 and 0.321 , respectively (World Bank, 2015). The real-life situation is decidedly different. It is also well known that a large segment of the Bangladeshi population survive on minimal income, which they use to purchase the very bare necessities of life. The daily diet of Bangladeshis is very meagre. The basic schooling opportunities for Bangladeshi children are considered as unaffordable, while in Britain, even the lowest segment of the society with the least income has access to the minimal necessities of life. The "meagre" British diet is considered to be extremely luxurious in the Bangladeshi context. Certainly, the basic schooling for children is freely available in Britain. Thus, in this assessment, actual qualitative economic inequality is very bad for the Bangladeshis and very tolerable for British people.

The income ratio of the richest $10 \%$ against the poorest $10 \%$ of the sample population (R/P 10\%) is also routinely used by many international institutions in order to quantify income inequality. The corresponding R/P 10\% of 13.8 for Britain and 7.5 for Bangladesh would seem to reinforce the depiction of Bangladesh as "less unequal" than Britain. But this $\mathrm{R} / \mathrm{P}$ parameter is largely meaningless because the ratio only quantifies the numerical difference. It does not reflect the true societal impact of the difference. For example, if the numerical value of the R/P 10\% is extremely high and if the bottom $10 \%$ have all the basic necessities of life provided either by the intervention of the State or by personal initiatives, then the actual impact of the "deprived" wellbeing of the poorest $10 \%$ will become trivial. In other words, it is inconsequential if the top $1 \%$ or $5 \%$ own everything in the scenario in which everyone in this poorest group is fed, sheltered and with unlimited access to quality health care and education. Thus, a simple comparison of the ratio of the earning of the richest $10 \%$ of the population against the poorest $10 \%$ of the population for different national societies has little or no meaning at all. What is important might be the adequacy of the livelihood of the bottom segment (i.e. minimum wage earners) of the society. The provision of the essential basic necessities of life for the poorest $10 \%$ of the population would be more critical than the delivery of an ever more ostentatious lifestyle for the 
segments of the society. After all, one can only eat so much food during a day as there is a physiological limit to food consumption by everyone. Similarly, one can only drive one automobile at any one time.

J. Stiglitz $(2010,84)$ argued that inequality matters because "The experience of Latin America, the region of the world with the highest level of inequality, foreshadows what lies ahead. Many of the countries were mired in a civil conflict for decades, suffered the high level of criminality and social instability....". This capitalism-centric foreboding is somewhat unfounded in view of the cornerstone principle of the modern business corporation. Transnational corporations are well-known for routinely co-opting national authorities (i.e. the ruling regimes) in order to wantonly exploit naturally-endowed resources, such as minerals, forestry, fishery, etc. and human resources so as to extract the maximum profit in the shortest possible time. There may in fact be no chaotic outcome if local ruling regimes, including politicians, senior officials and their cohorts, are bribed and coerced for the purpose of acting for the benefits of transnational corporations. Witness the endemic corruption in Africa as abetted by EUSAC transnational corporations with the active participation of their governments (Wong \& Gomes, 2014). In many instances, these nefarious activities are successfully carried out, with the interests of transnational corporations becoming increasingly indistinguishable from that of the home State. F. Braudel $(1977,64)$ has succinctly observed that "...Capitalism only triumphs when it becomes identified with the state, when it is the state." This situation is likened to many fundamental elements of the classical mercantilism of earlier centuries (Braudel, 1981). Notwithstanding any concern for (increasing) economic inequality, the exploitive regimes that rule with an iron fist for stability may last for many decades. In modern times, the malevolent ruling class has the additional unique "instant" mobility to move abroad in the event of any local social unrest and a civil strife manifesting itself beyond control. In practice, Stiglitz's "inequality matters" might be more aptly restated by saying that inequality does matter because it permits capitalists to efficiently make a greater profit. In essence, capitalism thrives on economic inequality.

\section{Societal Ills}

R. G. Wilkinson and K. E. Pickett (2009) have cited numerous issues of social dysfunction as caused by income inequality. S. Oishi, S. Kesebir and E. Diener (2011) have found that income inequality is related to happiness. The observations of these researchers are not unexpected as the lack of access to more material goods by the middle class is stressful in an ever-increasing consumerism society. This particular social dysfunction could, however, be expected to be different for the bottom segment of society, in which the provision of the bare necessities of life is a constant daily struggle. Interestingly, J. R. Chambers, L. K. Swan and M. Heesacker (2014); C. Starmans, M. Sheskin and P. Bloom (2017) have pointed out that income inequality (and its perception) is a matter of geographical relativity. R. H. Frank, A. S. Levine and O. Dijk (2014) have pointed out that the intensity of "wealth competition and envy" is the most prominent at the neighborhood level. This proposition concurs with the consequences of relentless consumerism in the EUSAC societies. Such analyses are, of course, only applicable to the middle-income segment of a society, in which "excessive consumerism" has an overbearing influence on the predicted adverse outcome.

\section{Is Income Inequality Unavoidable?}

In the EUSAC societies, more education attainment is routinely promoted as a means (especially for the young) to escape poverty. In turn, this paradigm is anticipated to render a society to be less economically unequal. While this action may be true for individuals, the problem of who would take the menial jobs vacated by the newly-educated class still remains? After all, these jobs are essential to the functioning of the broader EUSAC societies.

\section{Changing the Lifestyle of the Middle Class}

During the past 50 years, the lifestyle of the middle class has substantially changed in an increasing pursuit of economic wealth for personal hedonistic enjoyment. Two-income households in EUSAC have become very prevalent. In the past, most women had 
nearly always stayed at home (without any earned wages) to rear their children. As society, however, is irreversibly progressing towards having more women work routinely outside traditional homes, a new industry has been created collaterally to employ lower-paid child-minders, either collectively, in day-time child care centers, or singularly, with home-based child minders. Simple economics dictate that the marginal net income must be significantly higher for the person choosing to work outside the traditional home than employ a child-minder. This situation inevitably leads to income inequality.

\section{Menial jobs}

The same analysis could be applied to other menial tasks, such as cleaning public toilets, harvesting farmed crops, etc. for the purpose of maintaining the way of life of the middle-class. The notable European example of recent times is the purposeful mass importation of Gastarbeiters from Turkey into Germany during the 1960s. In that period of rapid economic growth in Germany, many Germans no longer wanted to perform low-paid menial (but essential) tasks. More recently, desperate migrants from East Europe, from the countries such as Moldova and Macedonia, have been permitted to enter Germany in order to do lowpaid farm-harvesting work in order to deliver certain seasonal crops to be consumed by the German public at large. Fundamentally, the deployment of lowpaid workers is an essential element for the normal economic functioning of modern German society. There may be no solution to this particular societal problem. The root of the problem might be the EUSAC's adherence (with many other emulating countries) to neoliberal economics. This paradigm is primarily predicated on the provision of financial rewards, among other things, to those who strive or connive to succeed, regardless of externalities. The moral issue, if any, is whether some EUSAC citizens are entitled to a disproportionately "good life" by the ever-expanding exploitation of others. Essentially, the attainment of a "better lifestyle" for the middle-income group depends on the availability of the low-cost service provided by the lower-income group. The blatant exploitation of (domestic) service workers consciously goes on.

\section{How Could Economic Inequality Be Remedied?}

\section{The Minimum Wage}

The minimum wage is the wage scale set by the government ostensibly to protect workers from being exploited by their employers. The level is intended to afford the minimum level of income for the worker's survival. There are numerous notable exemptions from the minimum-wage laws. In practice, the minimum wage is far below what is needed to purchase the essentials of life. Often, these workers need to work longer hours, perhaps several jobs, in order to provide minimum income adequacy.

Unfortunately, raising the minimum wage does not materially afford the "eradication of poverty" in the long term. Because there is no legal or moral control of subsequent price increases in free-market capitalist society, the only inevitable outcome is the creeping rise in the costs of the goods and services proffered by private enterprises in order to maintain at least the same or achieve an even higher profit margin. After all, a higher profit is the only invariable driving force of private enterprises. Thus, the relative position of the lowest group could be expected to remain ultimately unchanged by setting the minimum wage any higher. In essence, the rise in the minimum wage will always lag a consequential (disproportionate) rise in goods and services in free-market capitalist society.

\section{Better Education and Greater Skills}

According to T. Piketty $(2014,313)$, "the best way to increase wages and reduce wage inequalities in the long run is to invest in education and skills". This laudable, but simplistic proposition is predicated upon the better education and greater skillfulness of the workers who have previously been paid low wages, which has enabled them to enter into highpaid employment. The problem with this "remedy" is that there is still continuing demand for menial labor, which requires little or no education and skills at all. The unresolved question is how much should these menial-job workers be paid. The obvious answer is 
that these workers will always be paid minimally, according to the "what the market will bear" axiom of classical capitalism. It follows that the problem of the inadequate minimum wage and accompanying economic inequality could never be solved by this naïve remedial strategy.

\section{Is Income Equality Practicable in Contemporary Times?}

For over 5 decades, Cuba and the Democratic People's Republic of Korea have been operating under the communistic economic model in which personal (financial) wealth has effectively no relevancy. Based on the economic system of cooperative common weal, Cuba should have a Gini coefficient near zero, i.e. almost perfect equality. No Gini coefficient, however, has ever been calculated officially by the World Bank and others. The reason for this may lie in the fact that its publication would undermine the very foundation of the neoliberalism expounded by classical international institutions.

The other instructive case is the case of several types of present-day religious communities thriving without personal monetary income. Since the $19^{\text {th }}$ century, numerous self-sustaining Hutterrite ${ }^{4}$ colonies have been existent in Canada and the USA, without any income distributed to their individuals (Hofer, 1998; Kraybill \& Bowman, 2001; Janzen \& Stanton, 2010). A religious belief provides an alternative paradigm of righteous life in the absence of personal wealth. The Hutterites are notably well-provided with nutritious food, shelter, clothing, education and health care. There is notably no paid employment whatsoever for any persons living in the Hutterite colonies. Effectively, the Hutterites are the modernday practitioners of the classical social principle of common weal. The calculated Gini coefficient in this instance would be zero.

\section{CONCLUSION}

The originating question of this paper is whether economic inequality matters or not. The briefest answer is that it does not. This study has shown that:

- The classical methods of the quantification of economic inequality using such indices as the "Gini coefficient" and the "R/P 10\%" are deficient and largely misleading. The contemporary practice of monetization permits the facile convertibility of wealth (the holding of material goods) and income (cash).

- The construction of the veritable Lorenz curve is hindered by the lack of reliable economic data on the fraction of the population with the highest income (or greatest wealth). Tax avoidance, legal or otherwise, by the richest group distorts the national income statistics. Thus, the Gini coefficient calculated subsequently does not portray anything at all; it is merely a number calculated from an uncertain data base.

- The non-uniform shape of the Lorenz curve could render the same value of the Gini coefficient, but with very different social-economic consequences. In one instance, the specific value of the Gini coefficient might portray a situation of impending revolutionary-scale social unrest among the affected population. Yet, in another instance, the same value of the Gini coefficient could reflect the state of benign acceptance by the general population when all their expected material wealth is fully satisfied. In this latter instance, economic inequality does not matter at all, even if the richest segment of the population owns virtually everything.

- Income (wealth) inequality is a matter of relativity, dependent on physical geography and the socialcultural context. What is considered economic deprivation in one country might be considered as economic bountifulness in another.

In recent decades, income inequality has become the battle cry of the lower- and middle-income groups striving to reduce the ostentatious lifestyle of the upper-income group. Protesters' resentment in the EUSAC countries might be the only harmless outcome of the portrayed "gross economic inequality". After all, people in the EUSAC countries still enjoy a livable 
lifestyle. The highly publicized rage and resentment against the " $1 \%$ owning everything" in EUSAC may be greatly misplaced.

Because economic inequality is a mandatory manifestation of the practice of capitalism, there may be no solution to the rectification of genuine economic deprivation borne by the fraction of the population with the least income. The substantial re-configuration of modern-day capitalism, albeit presently somewhat impractical, is needed in order to achieve the societal goal of common weal.

\section{ENDNOTES}

1 The Gini Index is the Gini coefficient expressed as a percentage. The Gini Index measures the extent to which the distribution of income or consumption expenditure among individuals or households within an economy deviates from a perfectly equal distribution. The Lorenz curve plots the cumulative percentages of the total income received against the cumulative number of the recipients, starting with the poorest individual or household. The Gini Index measures the area between the Lorenz curve and the hypothetical line of absolute equality, expressed as a percentage of the maximum area under the line. Thus, the Gini Index of "o" represents perfect equality, whereas the index of "100" implies perfect inequality.

2 The Human Development Index (HDI) was invented so as to reflect the three principal parameters of human development, viz. life expectancy (the health status), educational attainment (literacy) and gross per capita income (personal wealth). There was a considerable disagreement about the value of these parameters in reflecting human wellbeing. It is, however, certainly useful when comparing states (countries) with a similar economic structure and status. For example, no HDI has ever been calculated for the countries such as Cuba and the Democratic Republic of Korea, in which the economic system is very different. Equatorial Guinea is a notable case, in which per capita income causes the HDI calculation to be grossly askew.

3 In 2007, there were nearly 10 million foreign workers residing in the Persian Gulf states (Manseau, 2007). The estimated number of the citizens in the states of the Gulf Cooperation Council (viz. Bahrain, Kuwait, Oman, Qatar, the United Arab Emirates and Saudi Arabia) was about 50 million in 2007 (http://www.gcc-sg.org/)
4 The Hutterites are Anabaptists (composed principally of pesants and artisans), having originated in the Tyrol region of Central Europe in the early $16^{\text {th }}$ Century (Chadwick, 1972, 192-194).

\section{REFERENCES}

Alstadsaeter, A., \& Martin, J. (2013). Who Participates in Tax Avoidance? CESifo Working Paper Series No. 4219. http:// www.cesifo-group.org/wp

Alstadsaeter, A., Johannesen, N., \& Zucman, G. (2017). Tax evasion and inequality. Oslo, Norway: School of Economics and Business, Norwegian University of Life Sciences. http:// gabriel-zucman.eu/files/AJZ2017.pdf

Anon. (2017). Saudi Arabia restores perks to state employees to fend off unrest. The Guardian - UK, 24 April. https://www. theguardian.com/world/2017/apr/24/saudi-arabia-restoresperks-to-state-employees-to-fend-off-unrest

Antuofermo, M., \& Di Meglio, E. (2012). 23\% of EU citizens were at risk of poverty or social exclusion in 2010. Statistics in Focus: Population and Social Conditions. Document 9/2012. Luxembourg: Eurostat. http://ec.europe.eu/eurostat

Barone, L., \& Guio, A.-C. (2005). In-work poverty. Statistics in Focus: Population and Social Conditions, Document 5/2005. Luxembourg: Eurostat. http://ec.europe.eu/eurostat

Braudel, F. (1977). Afterthoughts on Material Civilization and Capitalism. The Johns Hopkins Symposia in Comparative History. Translated by: P. Ranum. Baltimore: The Johns Hopkins University Press.

Braudel, F. (1981). Civilization and Capitalism, $15^{\text {th }}-18^{\text {th }}$ Century. New York, NY: Harper \& Row.

Chadwick, O. (1972). The Reformation. London, UK: Penguin Books.

Chambers, J. R., Swan, L. K., \& Heesacker, M. (2014). Better off than we know: Distorted perceptions of incomes and income inequality in America. Psychological Science, 25(2), 613-618. doi: 10.1177/0956797613504965

Cingano, F. (2014). Trends in income inequality and its impact on economic growth. OECD SEM Working Paper No. 163. Paris: Organization for Economic Cooperation and Development. www.oecd.org 
Dabla-Norris, E., Kochhar, K., Suphaphiphat, N., Ricka, F., \& Tsounta, E. (2015). Causes and consequences of income inequality: A Global Perspective. IMF Staff Discussion Note SDN.15/13. Washington, US: International Monetary Fund.

Dennis, I., \& Guio, A.-C. (2004). Poverty and social exclusion in the EU. Statistics in Focus: Population and Social Conditions, Document 16/2004. Luxembourg: Eurostat. http://ec.europe.eu/eurostat

Doran, J., \& Jordan, D. (2013). Decomposing European NUTS2 Regional Inequality from 1980 to 2009: National and European Policy Implications. MPRA Paper No. 44805, Munich Personal RePEc Archive. http://mpra.ub.unimuenchen.de/44805/

European Anti-Poverty Network Ireland - EAPNI (2017). Understanding poverty. http://www.eapn.ie/eapn/training/ consistent-poverty-rates

European Commission - EC (2017a). Earnings statistics. http:// ec.europa.eu/eurostat/statistics-explained/index.php/ Minimum_wage_statistics\#Proportion_of_minimum_ wage_earners European Commission - EC (2017b). Minimum wage statistics http://ec.europa.eu/eurostat/ statistics-explained/index.php/Earnings_statistics

EUROSTAT (2016). Statistics. http://epp.eurostat.ec.europa.eu/

Frank, R. H., Levine, A. S., \& Dijk, O. (2014). Expenditure cascades. Review ofBehavioral Economics, 1(1-2), 55-73. doi. org/10.1561/105.00000003

Friedman, M. (1962). Capitalism and Freedom. Chicago, US: The University of Chicago Press.

Friedman, M. (1970). The Social Responsibility of Business is to Increase its Profits. The New York Times Magazine, September 13.

Guio, A.-C. (2005). Material deprivation in the EU. Statistics in Focus: Population and Social Conditions, Document 21/2005. Luxembourg: Eurostat. http://ec.europe.eu/eurostat

Hofer, S. (1998). The Hutterites: Lives and Images of a Community People. Saskatoon, CA: Hofer Publishers.

International Trade Union Confederation - ITUC (2014). Facilitating exploitation: A review of labour laws for migrant domestic workers in Gulf Cooperation Council countries. Legal and Policy Brief, November. Brussels: ITUC. www.ituc-csi.org
Janzen, R., \& Stanton, M. (2010). The Hutterrites in North America. Baltimore, US: The Johns Hopkins University Press.

Kraybill, D. B., \& Bowman, C. F. (2001). On the Backroad to Heaven: Old Order Hutterites, Mennonites, Amish, and Brethren. Baltimore, US: The Johns Hopkins University Press.

MacCoun, R. J. (2001). American distortion of Dutch drug statistics. Society, 38(3), 23-26. doi.org/10.1007/BF02686215

Manseau, G. (2007). Contractual solutions for migrant labourers: The case of domestic workers in the middle east. Human Rights Law Commentary, 25-47. http:// www.nottingham.ac.uk/hrlc/documents/publications/ hrlcommentary2006/migrantlabourers.pdf

Milanovic, B. (2013). Global income inequality in numbers: in history and now. Global Policy, 4(2), 198-208.doi: 10.1111/1758-5899.12032

Milanovic, B. (2016). Global Inequality: A New Approach for The Age of Globalization. Massachusetts, US: Cambridge (MA), Belnap Press.

Oishi, S., Kesebir, S., \& Diener, E. (2011). Income inequality and happiness. Psychological Science, 22(9), 1095-1100. doi: 10.1177/0956797611417262

Organization for Economic Cooperation and Development - OECD (2014). Focus on Inequality and Growth: Does income inequality hurt economic growth? Paris: Directorate for Employment, Labour and Social Affairs, Organization for Economic Cooperation and Development. www. oecd.org

Oxford Dictionary. (2011). $9^{\text {th }}$ Edition. Oxford, UK: Oxford University Press

Peter, K. A. (1987). The Dynamics of Hutterite Society. Edmonton, CA: The University of Alberta Press.

Petrovic, V. (2012). Equatorial Guinea: Ignorance for fistfuls of dollars. Freedom House - US, 13 June. https:// freedomhouse.org/blog/equatorial-guinea-ignoranceworth-fistfuls-dollars

Piketty, T. (2014). Capital in the Twenty-First Century. Massachusetts, US: Harvard University Press.

Popkin, J. D. (2012). A Concise History of the Haitian Revolution. New York, NY: Wiley-Blackwell. 
Sahlins, M. (1972). Stone Age Economics. New York, NY: Aldine Publishing Company.

Slemrod, J. (2007). Cheating ourselves: The economics of tax evasion. Journal of Economic Perspectives, 21(1), 25-48. doi: 10.1257/jep.21.1.25

Starmans, C., Sheskin, M., \& Bloom, P. (2017). Why people prefer unequal societies. Nature Human Behaviour, 1. doi:10.1038/s41562-017-0082

Stiglitz, J. (2012). The Price of Inequality. New York, NY: W.W. Norton \& Company.

Sundiata, I.K. (1990). Equatorial Guinea: Colonialism, State Terror, and the Search for Stability. Boulder (CO): Westview Press.

United Nations Development Programme - UNDP (2015). Human Development Index. Published annually. www. undp.org

Webster, D. (2012). Unemployment: How official statistics distort analysis and policy, and why. Radical Statistics, Issue 79/80. http://www.radstats.org.uk/no079/webster. htm
Wilkinson, R. G., \& Pickett, K. E. (2009). Income inequality and social dysfunction. Annual Review of Sociology, 35, 493-511. doi: 10.1146/annurev-soc-070308-115926

Wong, A. (2016). Social upheaval, poverty and the Latvian demographic crisis. Finnish Yearbook of Population Research, 50, 97-126.

Wong, A., \& Gomes, R. (2014). Corruption in modern-day Africa: a possible remedy. Journal of Pan-African Studies, 7, 77-114.

World Bank (2015). Global Monitoring Report 2014/2015:Ending Poverty and Sharing Prosperity. Washington, DC. www. worldbank.org/content/dam/Worldbank/gmr/gmr2014/ GMR_2014_Full_Report.pdf.

World Bank (2016a). Gini Index. Washington (DC): The World Bank. http://data.worldbank.org/indicator/SI.POV.GINI/

World Bank (2016b). Poverty. www.worldbank.org/en/poverty (accessed 21 July 2016)

Zucman, G. (2014). Taxing across borders: Tracking personal wealth and corporate profits. Journal of Economic Perspectives, 28(4), 121-148. doi: 10.1257/jep.28.4.121

Received on $24^{\text {th }}$ June 2017, after one revision, accepted for publication on $23^{\text {rd }}$ August 2017. Published online on $25^{\text {th }}$ August 2017.

Alfred Wong is the Technical Director at Arbokem Inc., an independent technology research and management company based in Vancouver, Canada. He engages in research on the social, environmental and technology aspects of biomass energy systems.

Christine Ribeiro is a Research Associate at Arbokem Inc., Vancouver, Canada. She specializes in the analysis of social-economic issues. 


\title{
NEJEDNAKOST PRIHODA: DA LI JE ONA BITNA?
}

\author{
Alfred Wong i Christine Ribeiro \\ Arbokem Inc., Vancouver, Canada
}

Poslednjih godina, nejednakost prihoda je postala važna tema širom sveta. Rastuće nezadovoljstvo kod pripadnika onog sloja industrijalizovanih društava koji ostvaruje niže prihode se u velikoj meri svodi na ogorčenost zbog toga što se na ekonomsko bogatstvo gleda kao na bogatstvo koje se uporno koncentriše na sve manji broj ljudi. Kvantifikovana ekonomska nejednakost ne podrazumeva po svaku cenu ekstremno osiromašenje ljudi, posebno u Evropi i Severnoj Americi. Među pripadnicima srednje klase neće doći do izbijanja društvenih nemira, ukoliko se nastavi sa ispunjavanjem njihovih očekivanja u pogledu zadovoljavajućeg blagostanja. Veza između nejednakosti prihoda i siromaštva nije pouzdana upravo zbog varijabilne definicije siromaštva. Klasična definicija, odnosno, karakterizacija siromaštva je manjkava, jer stvarne ekonomske nedaće sa kojima se suočavaju pripadnici segmenta društva sa najnižim prihodima nikada nisu u potpunosti opisane u društveno-geografskom kontekstu. Ono što se u Evropi i Severnoj Americi smatra oskudicom, u ekonomski siromašnijim zemljama se smatra luksuzom.

Ključne reči: eksploatacija, nejednakost, minimalna zarada, siromaštvo, socijalna pravda

JEL Classification: D31, D33, D63, J31 